\title{
Review \\ CD26/DPP-4: Type 2 Diabetes Drug Target with Potential Influence on Cancer Biology
}

\author{
Emi Kawakita ${ }^{1}\left(\right.$, Daisuke Koya ${ }^{2,3}$ and Keizo Kanasaki ${ }^{1,3, *}$ \\ 1 Internal Medicine 1, Shimane University Faculty of Medicine, 89-1 Enya-cho, Izumo 693-8501, Japan; \\ kawakita@med.shimane-u.ac.jp \\ 2 Department of Diabetology \& Endocrinology, Kanazawa Medical University, Uchinada 920-0293, Japan; \\ koya0516@kanazawa-med.ac.jp \\ 3 Division of Anticipatory Molecular Food Science and Technology, Medical Research Institute, \\ Kanazawa Medical University, Uchinada 920-0293, Japan \\ * Correspondence: kkanasak@med.shimane-u.ac.jp; Tel.: +81-853-20-2183
}

Citation: Kawakita, E.; Koya, D.; Kanasaki, K. CD26/DPP-4: Type 2 Diabetes Drug Target with Potential Influence on Cancer Biology. Cancers 2021, 13, 2191. https://doi.org/ 10.3390/cancers13092191

Academic Editor: Oscar J. Cordero

Received: 24 February 2021

Accepted: 30 April 2021

Published: 2 May 2021

Publisher's Note: MDPI stays neutral with regard to jurisdictional claims in published maps and institutional affiliations.

Copyright: (c) 2021 by the authors. Licensee MDPI, Basel, Switzerland. This article is an open access article distributed under the terms and conditions of the Creative Commons Attribution (CC BY) license (https:// creativecommons.org/licenses/by/ $4.0 /)$.
Simple Summary: Dipeptidyl peptidase (DPP)-4 inhibitor is widely used for type 2 diabetes. Although DPP-4/CD26 has been recognized as both a suppressor and inducer in tumor biology due to its various functions, how DPP-4 inhibitor affects cancer progression in diabetic patients is still unknown. The aim of this review is to summarize one unfavorable aspect of DPP-4 inhibitor in cancer-bearing diabetic patients.

Abstract: DPP-4/CD26, a membrane-bound glycoprotein, is ubiquitously expressed and has diverse biological functions. Because of its enzymatic action, such as the degradation of incretin hormones, DPP-4/CD26 is recognized as the significant therapeutic target for type 2 diabetes (T2DM); DPP4 inhibitors have been used as an anti-diabetic agent for a decade. The safety profile of DPP- 4 inhibitors for a cardiovascular event in T2DM patients has been widely analyzed; however, a clear association between DPP-4 inhibitors and tumor biology is not yet established. Previous preclinical studies reported that DPP-4 suppression would impact tumor progression processes. With regard to this finding, we have shown that the DPP-4 inhibitor induces breast cancer metastasis and chemoresistance via an increase in its substrate C-X-C motif chemokine 12 , and the consequent induction of epithelial-mesenchymal transition in the tumor. DPP-4/CD26 plays diverse pivotal roles beyond blood glucose control; thus, DPP-4 inhibitors can potentially impact cancer-bearing T2DM patients either favorably or unfavorably. In this review, we primarily focus on the possible undesirable effect of DPP-4 inhibition on tumor biology. Clinicians should note that the safety of DPP-4 inhibitors for diabetic patients with an existing cancer is an unresolved issue, and further mechanistic analysis is essential in this field.

Keywords: DPP-4; epithelial-mesenchymal transition; CXCL12; type 2 diabetes; metformin

\section{Introduction}

Type 2 diabetes mellitus (T2DM) is associated with an increased risk of certain cancers and poor prognosis [1,2]. Mechanistically, hyperinsulinemia, insulin resistance, hyperglycemia, dyslipidemia, and chronic inflammation may promote cancer progression in T2DM patients. Moreover, the long-term use of anti-diabetic agents also potentially influences tumor behavior in diabetic patients with cancer $[3,4]$. Although large clinical trials to determine the safety of anti-diabetic drugs for cardiovascular outcome in diabetic patients have been performed, such a clinical study usually did not include those patients already known to have cancer, and observational intervals of trials to verify the impact of antidiabetic drugs on cancer progression are rare. Therefore, the safety profile of anti-diabetic agents on cancer-bearing diabetic patients has never been thoroughly evaluated. 
Dipeptidyl peptidase (DPP)-4 inhibitors are widely used for treatment in T2DM patients. DPP-4 is characterized as a T-cell differentiation antigen (CD26) and plays a multifunctional role through its enzymatic and nonenzymatic action. DPP-4 cleaves many substances, not only incretin hormones; DPP-4 inhibitors potentially increase many growth factors and chemokines that may induce cancer progression. Besides this, DPP-4 has many pivotal roles in immune function, inflammation, and antioxidative response. Therefore, the pleiotropic effects of DPP-4 inhibitors would not always be favorable, especially in cancer-bearing T2DM patients.

Since other authors have mentioned the favorable effects of DPP-4 suppression for cancer biology elsewhere [5-10], this review mainly focuses on the undesirable effects of DPP-4 inhibition in T2DM patients with cancer, including our preclinical data.

\section{The DPP-4 Gene Family}

This review fundamentally focused on DPP-4 for the Special Issue "CD26 and cancer" in this journal. However, introducing the general aspect of the biology of the DPP-4 gene family on cancer could help to understand the whole picture of this interesting peptidase family regarding cancer biology. Details are fully described elsewhere [11-14].

The DPP-4 gene family, a subgroup of the prolyl oligopeptidase family of enzymes, specializes in the cleavage of prolyl bonds. Among its family members, DPP-4, DPP-8, DPP9 , and fibroblast activation protein (FAP) display enzymatic action. The specific substrate or pathophysiological significance on cancer of DPP-8 and DPP-9 are not elucidated yet, but some tumor-promoting effects of either DPP- 8 or DPP-9 have been reported $[15,16]$. At the least. the inhibition of DPP-8 or DPP-9 could potentially influence the immune system and differentiation of certain cells. FAP is a very closely related enzyme to DPP-4 and exhibits higher levels in some cancers, especially in cancer-associated fibroblast. Indeed, the DPP-4 inhibitor linagliptin inhibited FAP as well [17].

\section{$D P P-4$}

DPP-4/CD26 is a cell surface glycoprotein expressed in various types of cells and tissues. The expression level of DPP-4 is incredibly high in the kidneys and small intestine. There are two forms of DPP-4: membrane-bound and soluble. The transmembrane protein domain of DPP-4 is anchored to the cell membrane, and its cytoplasmic domain is located at the N-terminus. The extracellular lesion of DPP-4 contains highly glycosylated, cysteinerich, and catalytic regions. The C-terminal loop of DPP-4 is vital for catalytic efficacy and dimerization [18]. A soluble form of DPP-4 (sDPP-4) is cleaved off the membrane by matrix metalloproteases [19] and exists in serum and other bodily fluids.

DPP-4 plays diverse biological functions through enzymatic-dependent and independent actions. For the enzymatic action, DPP-4 digests many polypeptides, including chemokines, neuropeptides, and incretin hormones such as glucagon-like peptide (GLP)-1 and glucose-dependent insulinotropic peptide [20]. Increased incretin hormones by DPP-4 inhibition leads to the glucose-dependent secretion of insulin; thus, the DPP-4 inhibitor is a widely prescribed drug for T2DM in clinics. DPP-4 also has molecular functions via interactions with adenosine deaminase, extracellular matrix (ECM) proteins, and caveolin-1 for non-enzymatic action. The roles on co-receptor activity for viral entry, cell proliferation and migration of DPP-4 are also reported [21-25]. The membrane-bound form of DPP-4 is also known to have a pivotal role in the interactions between integrin $\beta 1$ and ECM [26], by which integrins regulate the cytoskeletal organization and intracellular-signaling pathways $[27,28]$. We have reported that DPP-4 plays a profibrotic role through interaction with integrin $\beta 1$, and subsequently induces endothelial-mesenchymal transition [29].

In human serum, sDPP-4 plays a central role in enzymatic activity [30,31]. sDPP-4 induces cell signaling and human lymphocyte proliferation [32], independent of its catalytic action. In human adipocytes, skeletal muscle cells, and smooth muscle cells, sDPP-4 inhibits Akt activation [33]. The process of sDPP-4 synthesis is still not completely understood. Lamers et al. indicated that sDPP-4 is released from differentiated adipocytes more than 
preadipocytes, and that human adipocytes-secreted tumor necrosis factor- $\alpha$ and insulin increase both the levels of sDPP-4 and DPP-4 mRNA [33]. Others reported that the major sources of sDPP-4 are adipocytes and the liver. Additionally, DPP-4 inhibition increases the levels of sDPP-4 in plasma from endothelial or hematopoietic cells [34].

Since the diverse biological functions of DPP-4, cancer-promoting cytokine/ chemokine modulation and ECM interaction would be relevant to cancer cell behavior, DPP-4 inhibitors also potentially influence cancer cell biology beyond blood glucose control. Its biological effects are complex and different, depending on tumor types and the microenvironment.

\section{DPP-4 Expression in Primary Tumors}

DPP-4 is expressed in many solid tumors or hematologic malignancies (Table 1). The overexpression of DPP-4 in several cancers induces an anti-tumor effect [35,36]. DPP-4 in the primary tumor may have an essential role in regulating cancer biology, and DPP$4 / C D 26$ has also been noted as a potential biomarker of tumor progression. Mezawa et al. demonstrated that the decreased expression of CD26 is associated with poor prognosis in breast cancer patients. Furthermore, this decreased CD26 expression is attenuated by the suppression of transforming growth factor (TGF)- $\beta$ and C-X-C motif chemokine 12 (CXCL12) [37]. We also showed that DPP-4 ablation in a primary mammary tumor induced tumor growth and metastasis via the CXCL12-mediated pathway (Figure 1) [38]. In small cell lung cancer, DPP-4 levels were significantly diminished; however, restoration of DPP-4 induced apoptosis and cell cycle arrest via the p21 accumulation, and suppressed tumor growth and metastasis [39].

A

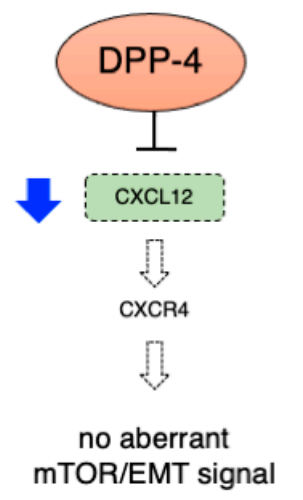

B

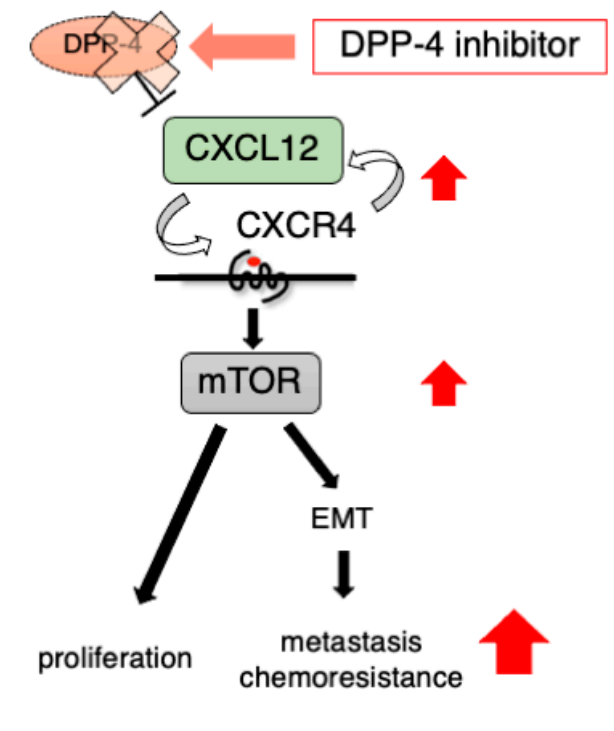

Figure 1. The impact of DPP-4 inhibitor on mammary tumor via CXCL12/CXCR4 downstream pathway. (A) DPP-4 digests CXCL12 for enzymatic action, thus the CXCL12-mediated CXCR4 downstream pathway in cancer is not strongly activated in the presence of DPP-4. (B) The DPP4 inhibitor suppresses the degradation of CXCL12 and increases the level of CXCL12. Elevated CXCL12 interacts with its receptor CXCR4 and induces mTOR activation. The DPP-4 inhibitorinduced CXCL12/CXCR4/mTOR pathway causes mammary tumor proliferation. The activation of mTOR also causes EMT, which induces metastasis and chemoresistance in the mammary tumor. CXCL12: C-X-C motif chemokine 12; CXCR4: C-X-C receptor 4; DPP-4: dipeptidyl peptidase-4; EMT: epithelial-mesenchymal transition; mTOR: mammalian target of rapamycin. 
Table 1. DPP-4/CD26 expression in primary tumors and its role in cancer progression processes.

\begin{tabular}{|c|c|c|}
\hline Tumor Type & Possible Association Between DPP-4/CD26 Expression in Tumors and Tumor Progression & Reference \\
\hline \multirow[t]{2}{*}{ Breast cancer } & Decreased stromal CD26 expression in tumors is associated with poor outcomes for BC patients. & [37] \\
\hline & DPP-4 knockdown in a primary mammary tumor induces tumor growth and metastasis in vivo. & [38] \\
\hline \multirow[t]{2}{*}{ Colorectal cancer } & $\begin{array}{l}\text { High expression levels of CD26 in tumors is associated with distant metastasis and worse overall survival in } \\
\text { CRC patients. }\end{array}$ & [40] \\
\hline & $\begin{array}{l}\text { Expression of stromal CD26 after preoperative CRT is associated with tumor recurrence and prognosis in rectal } \\
\text { cancer patients. }\end{array}$ & [41] \\
\hline Hepatocellular carcinoma & $\begin{array}{l}\text { Low levels of DPP- } 4 \text { expression in tumors are linked to the aggressiveness of HCC and poor overall survival in } \\
\text { HCC patients. }\end{array}$ & [42] \\
\hline Lung cancer & Restoration of DPP-4 expression in NSCLC cells contributes to inhibiting cell progression in vitro and in vivo. & [39] \\
\hline \multirow[t]{2}{*}{ Ovarian cancer } & $\begin{array}{l}\text { DPP-4 overexpression contributes to prolonged survival, decreased invasive activity, and increased } \\
\text { chemosensitivity in vitro and in vivo. }\end{array}$ & {$[43,44]$} \\
\hline & $\begin{array}{l}\text { DPP- } 4 \text { expression is associated with lymph node metastasis and a worse stage in tumor samples of ovarian } \\
\text { cancer patients. }\end{array}$ & [45] \\
\hline Pancreatic tumor & $\begin{array}{l}\text { CD26 expression is significantly increased in tumors and its level correlates with overall survival in PDAC } \\
\text { patients. }\end{array}$ & [46] \\
\hline Prostate cancer & $\begin{array}{l}\text { CD26 expression in prostate cancer tissues is correlated with CXCR4, PSA level, tumor residue, cancer stage, and } \\
\text { tumor size. }\end{array}$ & [47] \\
\hline Thyroid cancer & $\begin{array}{l}\text { CD26 expression is negatively correlated with GLP-1R expression and has no significant association with the } \\
\text { survival of patients with medullary thyroid carcinoma. }\end{array}$ & [48] \\
\hline Urothelial carcinoma & DPP-4 overexpression in tumors is associated with the clinical aggressiveness of UCs. & [49] \\
\hline \multirow[t]{3}{*}{ Hematological malignancies } & CD26 expression correlates with a poor response to $2^{\prime}$-deoxycoformycin in T-cell leukemia/lymphomas. & [50] \\
\hline & CD26 expression is associated with an unfavorable clinical outcome in B-CLL patients. & [51] \\
\hline & CD26 expression on B-CLL cells is associated with the tumor mass and influences time to treatment. & [52] \\
\hline
\end{tabular}

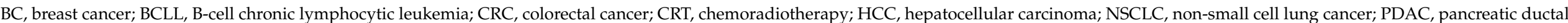
adenocarcinoma; UC, Urothelial carcinoma. 
On the other hand, an increased CD26 expression level has been associated with poor prognosis in pancreatic cancer patients [46] and other cancers [40,50]. DPP-4 expression in the primary tumor may regulate cancer behavior; however, the expression of DPP-4 in the primary tumor appears to be the heterogeneity patterns, depending on tumor type, stage, microenvironment, and host condition. It was also reported that DPP-4 expression and its secreted activity are uncoupled under hypoxia in ovarian cancer cells via the shedding of inactive DPP-4 from ovarian cancer cells [53]. Although several reports have suggested that the overexpression of DPP-4 would be a potential tumor prognosis marker in certain cancers, it is unresolved (1) how diverse functions of DPP-4 influence the cancer progression, and (2) whether DPP-4 inhibition is relevant as a therapy for patients with such DPP-4 overexpressed cancers. In addition, most reports about the correlation between DPP-4 expression in tumor and cancer prognosis did not mention whether patients had diabetic conditions or not. How the use of DPP-4 inhibitors impacts the DPP-4 expression of cancer in diabetic patients is not yet elucidated. It is essential to note that the clinical biomarkers are not always attributable to their biological importance in the disease activity; careful interpretation would be required.

\section{The Impact of DPP-4 Inhibition on Existing Tumors}

Several preclinical studies have addressed the potential link between DPP-4/CD26 and tumor progression. However, the mechanistic consequences of DPP-4 inhibition for a cancer-bearing individual are still not completely understood. Some studies described that the DPP-4 inhibitor is correlated with cancer cell invasiveness, metastasis and chemotherapy resistance in certain cancers. An early study by Beckenkamp et al. showed that the DPP-4 inhibitor sitagliptin increases cell migration and adhesion in cervical cancer cells [54]. Wang et al. also reported that the DPP-4 inhibitor saxagliptin and sitagliptin activate nuclear factor E2-related factor 2 (NRF2)-mediated antioxidant response, resulting in promoting metastasis of multiple tumors [55]. In papillary thyroid carcinoma cells, saxagliptin also promotes cancer cell migration and invasion through upregulation of NRF2 [56]. However, oxidative stress is known to suppress [57] or to induce [58] cancer invasion and metastasis. Redox balance plays an intricate role in cancer biology; DPP-4 inhibitors could also influence the tumor progression both favorably and unfavorably according to conditions.

For an alternative mechanism, DPP-4 inhibitors increase their substrate levels: neuropeptides, growth factors, cytokines, and chemokines. An elevated level of these substrates of DPP-4 can potentially influence cancer progression (Table 2).

CXCL12, and its receptor C-X-C receptor 4 (CXCR4), are related to hematopoiesis, angiogenesis, stem cell homing, and tumor progression and behavior $[59,60]$. Sun et al. reported that DPP-4 regulates prostate cancer metastasis in vitro and in vivo by the degradation of CXCL12 [61]. We also found that the DPP-4 inhibitor induces breast cancer metastasis via the inhibition of CXCL12 degradation. Accumulated CXCL12 interacted CXCR4 and contributed to CXCL12/CXCR4-mediated epithelial-mesenchymal transition (EMT) induction (Figure 1) [62]. Interestingly, EMT induction by DPP-4 inhibitor was independent of TGF- $\beta$ signaling. DPP-4 inhibitor-induced breast cancer metastasis was attenuated by the CXCR4 inhibitor AMD3100, with the suppression of genes associated with EMT and a mammalian target of rapamycin (mTOR) signaling pathway in the primary tumor $[38,62]$. The mTOR pathway is important for driving EMT processes in a mammary tumor $[63,64]$, and mTOR inhibition suppresses breast cancer proliferation, migration and metastasis [65-67]. In addition, some reports described the induction of the mTOR signaling pathway by DPP-4 inhibition $[62,68,69]$. In this regard, the activation of the mTOR pathway may be one of the critical factors for EMT induction by DPP-4 inhibition (Figure 1). However, in contrast, Varela-Calviño et al. recently reported that sitagliptin suppressed the metastatic potential of colorectal cancer cells in vitro [10]. Nevertheless, the effects of DPP-4 inhibitors on tumor metastasis remain unknown and further investigation is important. 
Table 2. Substrates of DPP-4/CD26 and potential downstream effect on tumor progression.

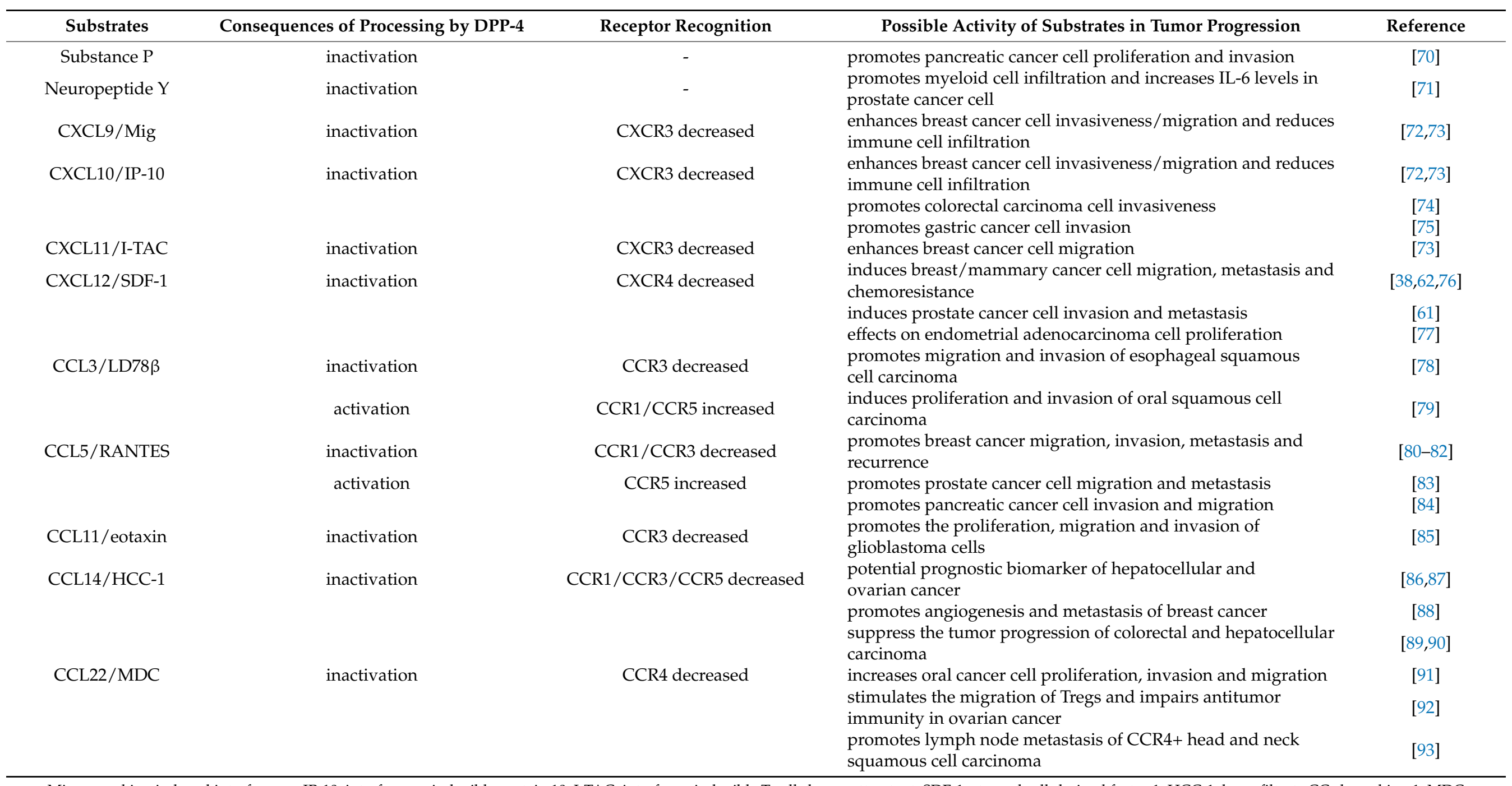


EMT is also relevant for chemotherapy resistance, not only for invasion or metastasis. Cells undergoing EMT processes are known to induce ATP-binding cassette (ABC) transporter overexpression, which is related to cancer drug resistance in several cancer cells [94,95]. With regard to this, we have reported that the DPP-4 inhibitor increases ABC transporters via EMT induction, resulting in breast cancer chemoresistance (Figure 1) [76]. A xenograft model of DPP-4-overexpressed epithelial ovarian cancer cells exhibited as larger bodies, but at the same time, displayed more chemosensitivity to paclitaxel [43]. Nevertheless, due to such heterogeneities in these preclinical studies, we should be carefully monitoring some potential influences, especially the unfavorable ones, of DPP-4 inhibitors in diabetic patients on cancer chemotherapy. Further mechanistic validation would be required.

\section{The Influence of DPP-4 Inhibitors on Cancer: Clinical Evidence}

Based on the current evidence from large clinical trials, DPP-4 inhibitors are safe for human health without significant concern about new onsets of cancers. Four cardiovascular outcomes trials (CVOTs) of DPP-4 inhibitors in T2DM patients represented that DPP-4 inhibitors (saxagliptin, alogliptin, sitagliptin, and linagliptin) had no statistically significant impact on cancer incidence, yet some trends of increased incidence of certain cancers are described (Table 3) [96-100]. The median follow-up periods were also short in order to evaluate the de novo carcinogenetic effect of DPP-4 inhibitors, and the number of cancer cases was limited in these trials (Table 3). Moreover, it is unknown whether DPP-4 inhibitors influence existing tumor growth, metastasis, and chemotherapy resistance because these trials excluded cancer-bearing diabetic patients.

Previous preclinical studies indicated that DPP-4 inhibitors could accelerate tumor growth and metastasis, not only the potential cancer-protective effects. Therefore, a prospective randomized trial to test the safety of DPP-4 inhibitors on cancer-bearing diabetic patients will never be performed. We cannot have a clear answer yet; however, clinicians should recognize the theoretical potential risks when prescribing DPP-4 inhibitors in cancer-bearing T2DM patients. 
Table 3. Cancer incidence in large clinical trials with DPP-4 inhibitors.

\begin{tabular}{|c|c|c|c|c|c|}
\hline & SAVOR-TIMI $53[96,100]$ & EXAMINE [97] & TECOS [98] & CARMELINA [99] & VERIFY [101] \\
\hline DPP-4 inhibitor & Saxagliptin & Alogliptin & Sitagliptin & Linagliptin & Vildagliptin + metformin \\
\hline Follow-up (years) & 2.1 & 1.5 & 3.0 & 2.2 & up to 5 \\
\hline Patients & 16,492 & 5380 & 14,671 & 6979 & 2001 \\
\hline Age (years) & 65.1 & 61.0 & 65.5 & 66.1 & 54 \\
\hline Body-mass index $*$ mean & 31.1 & 28.7 & 30.2 & 31.4 & 31.2 \\
\hline Glycated hemoglobin-mean (\%) & $8.0 \pm 1.4$ & $8.0 \pm 1.1$ & $7.2 \pm 0.5$ & 7.9 & 6.7 \\
\hline Duration of diabetes (years) & 10.3 & 7.1 & 11.6 & 15.0 & 3.3 (months) \\
\hline \multicolumn{6}{|l|}{ Metformin use-no. (\%) } \\
\hline Placebo-no. (\%) & $5684(69.2)$ & $1805(67.4)$ & $6030(82.2)$ & $1927(55.3)$ & all \\
\hline DPP-4 inhibitors-no. (\%) & $5789(69.9)$ & $1757(65.0)$ & $5936(81.0)$ & $1881(53.8)$ & all \\
\hline Inclusion criteria & $\begin{array}{c}\text { Established CVD, } \\
\text { multiple risk factors for VD }\end{array}$ & $\begin{array}{l}\text { An ACS with } 15 \text { to } 90 \text { days } \\
\text { before randomization }\end{array}$ & Established CVD & High CV and renal risk & $\begin{array}{c}\text { Diagnosed for type } 2 \text { diabetes } \\
\text { within } 2 \text { years prior to } \\
\text { enrolment }\end{array}$ \\
\hline Primary outcome & 3P-MACE & 3P-MACE & 4P-MACE & 3P-MACE & $\begin{array}{l}\text { The time from randomization } \\
\left.\text { to initial treatment failure }{ }^{*}\right)\end{array}$ \\
\hline Incidence of cancer & & & $* *$ & & \\
\hline P value & 0.15 & 0.77 & unknown & unknown & unknown \\
\hline Pancreatic cancer & & no reports & & & \\
\hline Placebo-no. $(\%)$ & 5 & - & $10(0.1)$ & $4(0.1)$ & $2(0.3) ※$ \\
\hline DPP-4 inhibitors-no. (\%) & 12 & - & $9(0.1)$ & $11(0.3)$ & $3(0.3) ※ *$ \\
\hline Other cancers-no. (\%) & unknown & unknown & unknown & Colon cancer & Prostate cancer \\
\hline & & & & Placebo: $8(0.2)$ & Met: 0 \\
\hline & & & & Linagliptin: $6(0.2)$ & Vildagliptin + Met: $6(0.6)$ \\
\hline & & & & Gastric cancer & Breast cancer \\
\hline & & & & Placebo: $3(0.1)$ & Met: 1 (0.1) \\
\hline & & & & Linagliptin: 0 & Vildagliptin + Met: $3(0.3)$ \\
\hline
\end{tabular}

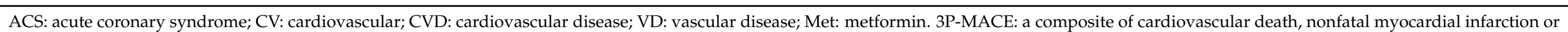

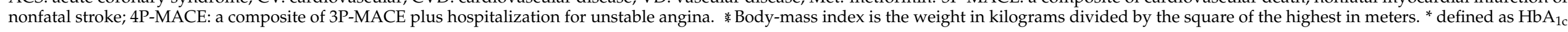

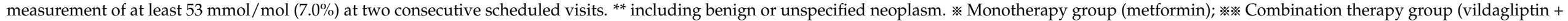
metformin). 


\subsection{The Impact of DPP-4 Inhibitors on Cancer Incidence in Diabetic Patients}

Observational studies and retrospective studies have discussed the link between DPP4 inhibitor use and cancer incidence in diabetic patients. DPP-4 inhibitor is one of the incretin-based drugs, by which the blood glucose-dependent secretion of insulin from pancreatic $\beta$ cells regulates blood glucose levels, and therefore is associated with a low risk of hypoglycemia with monotherapy. There has been some concern about an increased risk of certain cancers by incretin drugs, especially pancreatic cancer and thyroid cancer [102-105]; in contrast, later publications denied such a trend [106-114]. However, another retrospective study indicated incretin-based drugs are associated with an increased risk of pancreatic cancer with the adjusted hazard ratio (aHR) 2.14 (95\%CI: 1.71-2.67), compared with other oral antidiabetic drugs [115]. More recently, Lee et al. also reported that DPP-4 inhibitor users have a 50\% increased risk of pancreatic cancer incidence (aHR 1.50, 95\%CI: 1.02-2.20) among newly diagnosed T2DM patients. It is likely that such a risk was increased during the early exposure period of DPP-4 inhibitor prescription [116]. Sitagliptin also increased the risk of thyroid cancer only in the first year of its use [105]. These data suggested that DPP-4 inhibitors induce existing microtumor/precancerous cell visibility rather than inducing de novo carcinogenesis. On the other hand, a propensity-matched cohort study of T2DM patients in Korea represented that DPP-4 inhibitor treatment did not increase the risk of pancreatic and thyroid cancer compared to metformin treatment [117].

Abrahami et al. [118] showed the association between incretin-based drugs and an increased risk of cholangiocarcinoma in T2DM patients. In this study, the incidence of cholangiocarcinoma is significantly increased by $77 \%$ in DPP-4 inhibitor users (HR 1.77, 95\%CI: 1.04-3.01), and an increasing trend in GLP-1 receptor agonist (GLP-1RA) users as well (HR 1.97, 95\%CI: 0.83-4.66). The undesirable effect of DPP-4 inhibitors remained significant after adjusting with sulfonylurea users [118]. These drugs increase the plasma levels of GLP-1 or GLP-1RA, which may stimulate cholangiocarcinoma proliferation and anti-apoptotic response [119-121]. In addition to the elevated level of endogenous GLP1, DPP-4 inhibitor administration increases numerous substrates that also influence the tumor microenvironment and the immune system, which are essential for tumor onset. Cholangiocarcinoma is a rare cancer type; therefore, this could be the result of prescription biases. However, also such a finding could be a sign of the risk of DPP-4 inhibitors in certain cancers, and it should not be overlooked. In contrast, DPP-4 inhibitor users had no elevated risk of colorectal cancer incidence in diabetic patients [122], and that the DPP-4 inhibitor was also associated with a significantly reduced risk of colorectal cancer among T2DM patients [123].

As mentioned above, there are several studies about the relationship between DPP4 inhibitors and site-specific cancer incidence. Based on the available clinical reports, however, the incidence of cancer is not significantly related to the DPP-4 inhibitor prescription when adjusted by cofounders [124]. A meta-analysis of randomized clinical trials showed that DPP-4 inhibitors were not related to an increased risk of developing cancers compared to a placebo or other anti-diabetic drugs in T2DM patients [125]. Other meta-analyses also reported that DPP-4 inhibitors did not increase the risk of cancers of the digestive system [126] or overall cancers [123]. The conclusion by clinical analysis when examining the association between DPP-4 inhibitor and cancer incidence is influenced by diverse factors. Firstly, the follow-up period was short for validating the impact of anti-diabetic drugs on cancer incidence. Secondly, the number of patients using DPP-4 inhibitors alone was limited. Patients who are prescribed DPP-4 inhibitors as a second- or third-line anti-diabetic drug often display poor blood glucose control, which potentially promotes cancer initiation [127]. Nevertheless, in the information obtained from these observational, retrospective, or cohort studies, complete elimination of significant biases would never be possible; therefore, careful consideration is required to interpret these data. Both a preclinical study and larger clinical studies with a longer term are needed to confirm the safety of DPP-4 inhibitors for cancer incidence. 


\subsection{The Influence of DPP-4 Inhibitors on Cancer Prognosis and Metastasis}

SEER- and Medicare-linked database analysis indicated that T2DM patients taking a DPP-4 inhibitor had a worse trend of overall survival (OS) with HR 1.07 (95\%CI: 0.93$1.25, p=0.33$ ) in the breast cancer cohort and HR 1.07 (95\%CI: 0.93-1.24, $p=0.68$ ) in the pancreatic cancer cohort, whereas DPP-4 inhibitor use had significant OS benefit with HR 0.77 (95\%CI: 0.64-0.93, $p=0.005$ ) in patients with prostate cancer [128]. Ali et al. reported DPP-4 inhibitor had a positive effect on progression-free survival in patients with advanced airway and colorectal cancers and diabetes by a multicenter retrospective analysis [129].

Cancer metastasis and chemotherapy resistance are important factors for the prognosis of cancer patients. Preclinical studies have reported that DPP-4 inhibitors potentially increase the risk of tumor metastasis [55]. A cohort study in Korea represented that the DPP-4 inhibitor increases newly onset metastasis of primary thyroid cancer in diabetic patients [130]. Rathmann et al. performed the observational study, utilizing a database of ICD code filled in by primary care physicians, to analyze the association between DPP-4 inhibitor therapy and the risk of metastasis in T2DM patients with newly diagnosed breast, prostate and digestive organ cancers [131]. In this observational study, DPP-4 inhibitors did not increase a risk of metastasis in T2DM patients with breast (aHR 1.00, 95\%CI: 0.49-2.02), prostate $(0.98,0.54-1.77)$ or digestive organ cancers $(0.97,0.57-1.66)$ [131].

As with the association between DPP-4 inhibitor use and newly diagnosed cancer, the conclusions on the effect of DPP-4 inhibitors on cancer prognosis and metastasis differed with factors such as cancer type or patient profile. Nevertheless, the currently available clinical study indicated that there is no significant risk of a cancer prognosis and metastasis among cancer-bearing diabetic patients on DPP-4 inhibitor therapy. Importantly, the retrospective analysis gives us some hypotheses, but the absence of information about cancer characteristics, such as its stage or receptor expression, makes it difficult to interpret these data. On top of that, diabetes is an independent risk factor for cancer progression, thus epidemiological studies investigating the association between anti-diabetic drugs and cancer outcomes come with diverse, unavoidable limitations. Recently, Vihervuori et al. reported that the use of an anti-diabetic agent, especially metformin and insulin, was associated with the worse prognoses in patients with prostate cancer [132]. This result may suggest that the presence of diabetes with metabolic abnormalities such as hyperglycemia or insulin resistance displays stronger influences on prostate cancer progression, rather than specific drug use. Indeed, hyperglycemia and/or insulin resistance are linked to a worse prognosis of cancer patients [133-135]. Therefore, it is challenging to evaluate the effect of specific anti-diabetic drugs on cancer progression in diabetic patients with retrospective analysis.

Furthermore, a clinical report exploring the impact of DPP-4 inhibitors on chemotherapy outcomes in diabetic patients with cancer is lacking. In previous preclinical studies, either EMT or increased CXCL12 level, the condition associated with DPP-4 inhibition, is relevant for chemoresistance $[76,136,137]$. DPP-4 also plays an important role in the immune system, especially T-cell functions. A clinical trial investigating the outcome of chemotherapy, including immune-checkpoint inhibitors, for cancer-bearing diabetic patients with DPP-4 inhibitors is also required.

\section{Perspective: Co-Prescription with Metformin}

We have recently reported that metformin mitigates DPP-4 inhibitor-induced breast cancer EMT and metastasis via the suppression of mTOR activation [38]. Metformin is the first-line drug for T2DM, and thus, metformin is often prescribed with other antidiabetic drugs. Metformin has been also recognized as an anti-cancer agent for some time; metformin users among diabetic patients displayed a decreased risk of colorectal, pancreatic and breast cancer compared to metformin non-users [138,139]. Metformin also exhibits a protective effect on overall cancer morbidity and mortality [140]. Additionally, some reports indicated the possibility that metformin impacts the cancer-related outcome on DPP-4 inhibitor use in diabetic patients. Retrospective analysis data represents that 
breast cancer-bearing diabetic patients taking metformin had significant OS benefit either with or without DPP-4 inhibitors, whereas DPP-4 inhibitors alone displayed a worse trend [128]. In this regard, DPP-4 inhibitor treatment among T2DM patients with colorectal and lung cancers represents a significant survival advantage alongside metformin, whereas DPP-4 inhibitor treatment alone did not reach a significant survival benefit [7].

Regarding the effect on cancer metastasis, the co-prescription of metformin with DPP-4 inhibitors could prevent an elevated risk of thyroid cancer metastasis with DPP-4 inhibitor alone in T2DM patients [130]. Noh et al. reported that using a DPP-4 inhibitor alone increases the metastasis of primary thyroid cancer with HR 3.89 (95\%CI: 1.04-9.64) in T2DM patients, whereas a combination with metformin attenuated such an undesirable effect of DPP-4 inhibitor (HR 0.75, 95\%CI: 0.57-1.01) [130]. This clinical evidence suggests the effect of a DPP-4 inhibitor on cancer progression in T2DM patients with certain cancers differs depending on whether it is co-prescribed with metformin. However, Matthews et al. reported that in their analysis, even under a combination therapy with metformin, DPP-4 inhibitor vildagliptin prescription increased the trend of prostate and breast cancer incidence when compared to metformin alone (Table 3) [101].

Interestingly, our preclinical data demonstrated that metformin represents anti-tumor/ anti-metastatic effect only when prescribed with a DPP-4 inhibitor; nevertheless, metformin alone had no impact on basal breast cancer proliferation and metastasis in vivo [38]. Indeed, some randomized trials showed no impact of metformin on breast cancer progression and prognosis [141-143], even though several preclinical data have reported the anti-tumor effect of metformin in breast cancer. Further mechanistic investigation is definitely needed, using metformin as an anti-tumor agent in a clinical setting. Metformin may preferentially target mesenchymal cells or stem cells [144-146], indicating some clue as to the beneficial effects of metformin on human health. DPP-4 inhibition advances the EMT process of cancer cells to a more mesenchymal phenotype, relating to cancer migration, invasiveness, metastasis, chemoresistance, or stemness. Therefore, metformin may have more anti-tumor influence on a mammary tumor when co-prescribed with DPP-4 inhibitors, compared with metformin alone (Figure 2). Because DPP-4 inhibitors are often prescribed with other anti-diabetic drugs, the differences induced by the interaction of drugs are also of interest.

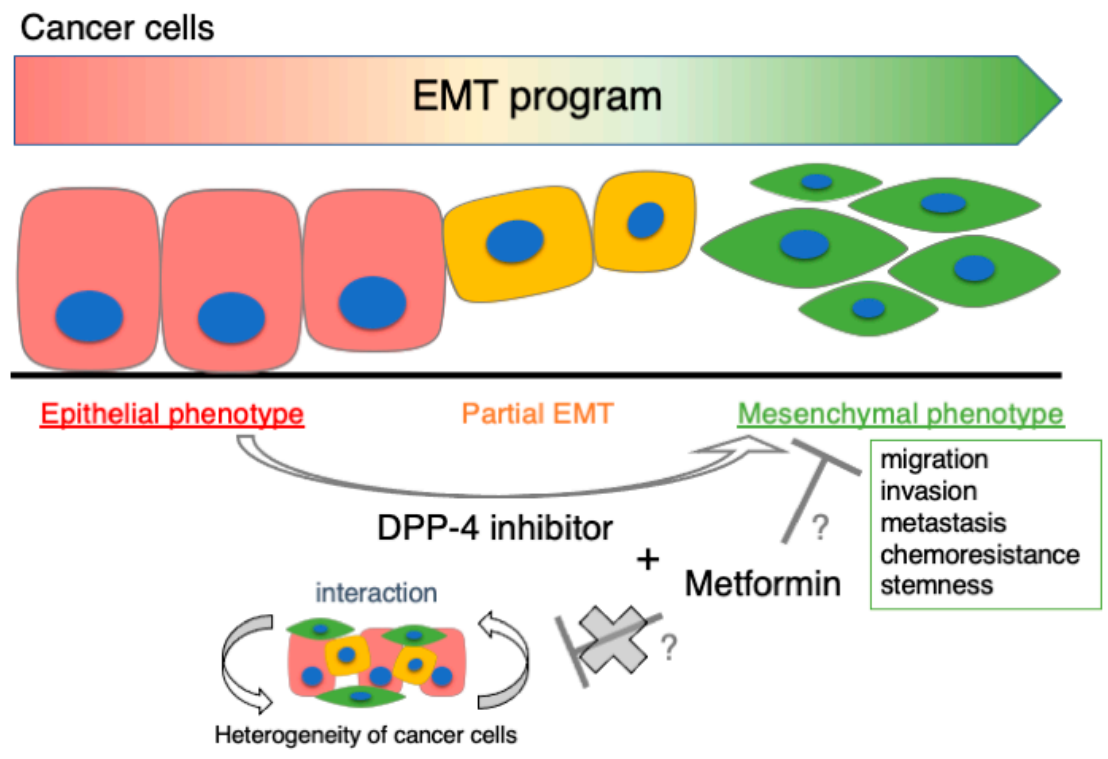

Figure 2. DPP-4 inhibitor-induced cancer progression is attenuated by metformin. Cancer cells exist in various phases of the EMT process; epithelial-like, mesenchymal-like, or partial phenotype of cancer cells. These heterogeneous cancer cell populations interact with each other and effectively develop in cancer biology. The DPP-4 inhibitor progresses cancer cells to a more mesenchymal phenotype, which is associated with tumor progressions such as migration, invasion, metastasis, chemoresistance and stemness. Metformin is likely to have an anti-tumor effect on homogenous mesenchymal cancer cell population induced by DPP-4 inhibitor. DPP-4: dipeptidyl peptidase-4; EMT: endothelial-mesenchymal transition. 


\section{Conclusions}

As DPP-4/CD26 has various vital functions in cancer biology, DPP-4 inhibitors potentially act as either suppressors or inducers in cancer development. Available clinical evidence has indicated no clear association as yet between DPP-4 inhibitors and cancer incidence or prognosis in diabetic patients. However, importantly, the safety profile of a DPP-4 inhibitor (the same as other anti-diabetic drugs) on cancer progression of existing cancer or recurrence has not yet been established. Thus, further mechanistic investigations about the link between DPP-4 inhibitors and cancer biology, especially in diabetic conditions, are an essential research topic in both diabetology and oncology.

Author Contributions: Conceptualization, E.K. and K.K.; literature search, E.K.; writing—original draft preparation, E.K.; writing—review and editing, K.K.; visualization, E.K.; supervision, D.K.; funding acquisition, K.K. All authors have read and agreed to the published version of the manuscript.

Funding: This research was funded by a grant from the Japan Diabetes Foundation (2016), and partially supported by grants from the Japan Society for the Promotion of Science (19K08738) and Uehara Memorial Foundation to K.K. K.K. has also collaborated with Boehringer Ingelheim at the Kanazawa Medical University and Shimane University. Boehringer Ingelheim, Mitsubishi-Tanabe Pharma and Ono Pharmaceutical have all contributed to establishing the Division of Anticipatory Molecular Food Science and Technology. K.K. is currently working under a consultancy agreement with Boehringer Ingelheim.

Conflicts of Interest: The authors declare no conflict of interest.

\section{References}

1. Onitilo, A.A.; Engel, J.M.; Glurich, I.; Stankowski, R.V.; Williams, G.M.; Doi, S.A. Diabetes and cancer I: Risk, survival, and implications for screening. Cancer Cause Control 2012, 23, 967-981. [CrossRef] [PubMed]

2. Barone, B.B.; Yeh, H.C.; Snyder, C.F.; Peairs, K.S.; Stein, K.B.; Derr, R.L.; Wolff, A.C.; Brancati, F.L. Long-term all-cause mortality in cancer patients with preexisting diabetes mellitus: A systematic review and meta-analysis. JAMA 2008, 300, 2754-2764. [CrossRef]

3. Walker, J.J.; Johnson, J.A.; Wild, S.H. Diabetes treatments and cancer risk: The importance of considering aspects of drug exposure. Lancet Diabetes Endocrinol. 2013, 1, 132-139. [CrossRef]

4. Sen, S.; He, Y.; Koya, D.; Kanasaki, K. Cancer biology in diabetes. J. Diabetes Investig. 2014, 5, 251-264. [CrossRef] [PubMed]

5. Jang, J.H.; Janker, F.; De Meester, I.; Arni, S.; Borgeaud, N.; Yamada, Y.; Gil Bazo, I.; Weder, W.; Jungraithmayr, W. The CD26/DPP4inhibitor vildagliptin suppresses lung cancer growth via macrophage-mediated NK cell activity. Carcinogenesis 2019, 40, 324-334. [CrossRef] [PubMed]

6. Nishina, S.; Yamauchi, A.; Kawaguchi, T.; Kaku, K.; Goto, M.; Sasaki, K.; Hara, Y.; Tomiyama, Y.; Kuribayashi, F.; Torimura, T.; et al. Dipeptidyl Peptidase 4 Inhibitors Reduce Hepatocellular Carcinoma by Activating Lymphocyte Chemotaxis in Mice. Cell Mol. Gastroenterol. Hepatol. 2019, 7, 115-134. [CrossRef]

7. Bishnoi, R.; Hong, Y.R.; Shah, C.; Ali, A.; Skelton, W.P.t.; Huo, J.; Dang, N.H.; Dang, L.H. Dipeptidyl peptidase 4 inhibitors as novel agents in improving survival in diabetic patients with colorectal cancer and lung cancer: A Surveillance Epidemiology and Endpoint Research Medicare study. Cancer Med. 2019, 8, 3918-3927. [CrossRef]

8. Enz, N.; Vliegen, G.; De Meester, I.; Jungraithmayr, W. CD26/DPP4-A potential biomarker and target for cancer therapy. Pharmacol. Ther. 2019, 198, 135-159. [CrossRef]

9. Davies, S.; Beckenkamp, A.; Buffon, A. CD26 a cancer stem cell marker and therapeutic target. Biomed. Pharmacother. 2015, 71, 135-138. [CrossRef]

10. Varela-Calvino, R.; Rodriguez-Quiroga, M.; Dias Carvalho, P.; Martins, F.; Serra-Roma, A.; Vazquez-Iglesias, L.; Paez de la Cadena, M.; Velho, S.; Cordero, O.J. The mechanism of sitagliptin inhibition of colorectal cancer cell lines' metastatic functionalities. IUBMB Life 2021, 73, 761-773. [CrossRef]

11. Yu, D.M.; Yao, T.W.; Chowdhury, S.; Nadvi, N.A.; Osborne, B.; Church, W.B.; McCaughan, G.W.; Gorrell, M.D. The dipeptidyl peptidase IV family in cancer and cell biology. FEBS J. 2010, 277, 1126-1144. [CrossRef]

12. Pure, E.; Blomberg, R. Pro-tumorigenic roles of fibroblast activation protein in cancer: Back to the basics. Oncogene 2018, 37, 4343-4357. [CrossRef] [PubMed]

13. Fitzgerald, A.A.; Weiner, L.M. The role of fibroblast activation protein in health and malignancy. Cancer Metastasis Rev. 2020, 39, 783-803. [CrossRef]

14. Zhang, H.; Chen, Y.; Keane, F.M.; Gorrell, M.D. Advances in understanding the expression and function of dipeptidyl peptidase 8 and 9. Mol. Cancer Res. 2013, 11, 1487-1496. [CrossRef]

15. Brunetti, M.; Holth, A.; Panagopoulos, I.; Staff, A.C.; Micci, F.; Davidson, B. Expression and clinical role of the dipeptidyl peptidases DPP8 and DPP9 in ovarian carcinoma. Virchows Arch. 2019, 474, 177-185. [CrossRef] [PubMed] 
16. Johnson, D.C.; Taabazuing, C.Y.; Okondo, M.C.; Chui, A.J.; Rao, S.D.; Brown, F.C.; Reed, C.; Peguero, E.; de Stanchina, E.; Kentsis, A.; et al. DPP8/DPP9 inhibitor-induced pyroptosis for treatment of acute myeloid leukemia. Nat. Med. 2018, 24, 1151-1156. [CrossRef] [PubMed]

17. Schnapp, G.; Hoevels, Y.; Bakker, R.A.; Schreiner, P.; Klein, T.; Nar, H. A Single Second Shell Amino Acid Determines Affinity and Kinetics of Linagliptin Binding to Type 4 Dipeptidyl Peptidase and Fibroblast Activation Protein. ChemMedChem 2021, 16, 630-639. [CrossRef]

18. Chien, C.H.; Huang, L.H.; Chou, C.Y.; Chen, Y.S.; Han, Y.S.; Chang, G.G.; Liang, P.H.; Chen, X. One site mutation disrupts dimer formation in human DPP-IV proteins. J. Biol. Chem. 2004, 279, 52338-52345. [CrossRef] [PubMed]

19. Rohrborn, D.; Eckel, J.; Sell, H. Shedding of dipeptidyl peptidase 4 is mediated by metalloproteases and up-regulated by hypoxia in human adipocytes and smooth muscle cells. FEBS Lett. 2014, 588, 3870-3877. [CrossRef]

20. Mulvihill, E.E.; Drucker, D.J. Pharmacology, physiology, and mechanisms of action of dipeptidyl peptidase-4 inhibitors. Endocr Rev. 2014, 35, 992-1019. [CrossRef]

21. Kameoka, J.; Tanaka, T.; Nojima, Y.; Schlossman, S.F.; Morimoto, C. Direct association of adenosine deaminase with a T cell activation antigen, CD26. Science 1993, 261, 466-469. [CrossRef] [PubMed]

22. Lambeir, A.M.; Durinx, C.; Scharpe, S.; De Meester, I. Dipeptidyl-peptidase IV from bench to bedside: An update on structural properties, functions, and clinical aspects of the enzyme DPP IV. Crit. Rev. Clin. Lab. Sci. 2003, 40, 209-294. [CrossRef]

23. Lopez-Otin, C.; Matrisian, L.M. Emerging roles of proteases in tumour suppression. Nat. Rev. Cancer 2007, 7, 800-808. [CrossRef] [PubMed]

24. Lu, G.; Hu, Y.; Wang, Q.; Qi, J.; Gao, F.; Li, Y.; Zhang, Y.; Zhang, W.; Yuan, Y.; Bao, J.; et al. Molecular basis of binding between novel human coronavirus MERS-CoV and its receptor CD26. Nature 2013, 500, 227-231. [CrossRef]

25. Kahne, T.; Lendeckel, U.; Wrenger, S.; Neubert, K.; Ansorge, S.; Reinhold, D. Dipeptidyl peptidase IV: A cell surface peptidase involved in regulating T cell growth (review). Int. J. Mol. Med. 1999, 4, 3-15. [CrossRef] [PubMed]

26. Sato, T.; Yamochi, T.; Yamochi, T.; Aytac, U.; Ohnuma, K.; McKee, K.S.; Morimoto, C.; Dang, N.H. CD26 regulates p38 mitogenactivated protein kinase-dependent phosphorylation of integrin beta1, adhesion to extracellular matrix, and tumorigenicity of T-anaplastic large cell lymphoma Karpas 299. Cancer Res. 2005, 65, 6950-6956. [CrossRef] [PubMed]

27. Luo, B.H.; Carman, C.V.; Springer, T.A. Structural basis of integrin regulation and signaling. Annu. Rev. Immunol. 2007, 25, 619-647. [CrossRef] [PubMed]

28. Arnaout, M.A.; Goodman, S.L.; Xiong, J.P. Structure and mechanics of integrin-based cell adhesion. Curr. Opin. Cell Biol. 2007, 19, 495-507. [CrossRef]

29. Shi, S.; Srivastava, S.P.; Kanasaki, M.; He, J.; Kitada, M.; Nagai, T.; Nitta, K.; Takagi, S.; Kanasaki, K.; Koya, D. Interactions of DPP-4 and integrin beta1 influences endothelial-to-mesenchymal transition. Kidney Int. 2015, 88, 479-489. [CrossRef]

30. Durinx, C.; Lambeir, A.M.; Bosmans, E.; Falmagne, J.B.; Berghmans, R.; Haemers, A.; Scharpe, S.; De Meester, I. Molecular characterization of dipeptidyl peptidase activity in serum: Soluble CD26/dipeptidyl peptidase IV is responsible for the release of X-Pro dipeptides. Eur. J. Biochem. 2000, 267, 5608-5613. [CrossRef] [PubMed]

31. Cordero, O.J.; Salgado, F.J.; Nogueira, M. On the origin of serum CD26 and its altered concentration in cancer patients. Cancer Immunol. Immunother. 2009, 58, 1723-1747. [CrossRef] [PubMed]

32. Yu, D.M.; Slaitini, L.; Gysbers, V.; Riekhoff, A.G.; Kahne, T.; Knott, H.M.; De Meester, I.; Abbott, C.A.; McCaughan, G.W.; Gorrell, M.D. Soluble CD26/dipeptidyl peptidase IV enhances human lymphocyte proliferation in vitro independent of dipeptidyl peptidase enzyme activity and adenosine deaminase binding. Scand. J. Immunol. 2011, 73, 102-111. [CrossRef]

33. Lamers, D.; Famulla, S.; Wronkowitz, N.; Hartwig, S.; Lehr, S.; Ouwens, D.M.; Eckardt, K.; Kaufman, J.M.; Ryden, M.; Muller, S.; et al. Dipeptidyl peptidase 4 is a novel adipokine potentially linking obesity to the metabolic syndrome. Diabetes 2011, 60 , 1917-1925. [CrossRef]

34. Varin, E.M.; Mulvihill, E.E.; Beaudry, J.L.; Pujadas, G.; Fuchs, S.; Tanti, J.F.; Fazio, S.; Kaur, K.; Cao, X.; Baggio, L.L.; et al. Circulating Levels of Soluble Dipeptidyl Peptidase-4 Are Dissociated from Inflammation and Induced by Enzymatic DPP4 Inhibition. Cell Metab. 2019, 29, 320-334.e325. [CrossRef]

35. Wesley, U.V.; McGroarty, M.; Homoyouni, A. Dipeptidyl peptidase inhibits malignant phenotype of prostate cancer cells by blocking basic fibroblast growth factor signaling pathway. Cancer Res. 2005, 65, 1325-1334. [CrossRef]

36. Arscott, W.T.; LaBauve, A.E.; May, V.; Wesley, U.V. Suppression of neuroblastoma growth by dipeptidyl peptidase IV: Relevance of chemokine regulation and caspase activation. Oncogene 2009, 28, 479-491. [CrossRef] [PubMed]

37. Mezawa, Y.; Daigo, Y.; Takano, A.; Miyagi, Y.; Yokose, T.; Yamashita, T.; Morimoto, C.; Hino, O.; Orimo, A. CD26 expression is attenuated by TGF-beta and SDF-1 autocrine signaling on stromal myofibroblasts in human breast cancers. Cancer Med. 2019, 8 , 3936-3948. [CrossRef]

38. Kawakita, E.; Yang, F.; Kumagai, A.; Takagaki, Y.; Kitada, M.; Yoshitomi, Y.; Ikeda, T.; Nakamura, Y.; Ishigaki, Y.; Kanasaki, K.; et al. Metformin Mitigates DPP-4 Inhibitor-Induced Breast Cancer Metastasis via Suppression of mTOR Signaling. Mol. Cancer Res. 2021, 19, 61-73. [CrossRef]

39. Wesley, U.V.; Tiwari, S.; Houghton, A.N. Role for dipeptidyl peptidase IV in tumor suppression of human non small cell lung carcinoma cells. Int. J. Cancer 2004, 109, 855-866. [CrossRef] [PubMed]

40. Lam, C.S.; Cheung, A.H.; Wong, S.K.; Wan, T.M.; Ng, L.; Chow, A.K.; Cheng, N.S.; Pak, R.C.; Li, H.S.; Man, J.H.; et al. Prognostic significance of CD26 in patients with colorectal cancer. PLoS ONE 2014, 9, e98582. [CrossRef] [PubMed] 
41. Saigusa, S.; Toiyama, Y.; Tanaka, K.; Inoue, Y.; Mori, K.; Ide, S.; Imaoka, H.; Kawamura, M.; Mohri, Y.; Kusunoki, M. Prognostic relevance of stromal CD26 expression in rectal cancer after chemoradiotherapy. Int. J. Clin. Oncol. 2016, 21, 350-358. [CrossRef]

42. Yu, H.; Mei, X.P.; Su, P.F.; Jin, G.Z.; Zhou, H.K. A poor prognosis in human hepatocellular carcinoma is associated with low expression of DPP4. Braz. J. Med. Biol. Res. 2020, 53, e9114. [CrossRef] [PubMed]

43. Kajiyama, H.; Shibata, K.; Ino, K.; Mizutani, S.; Nawa, A.; Kikkawa, F. The expression of dipeptidyl peptidase IV (DPPIV/CD26) is associated with enhanced chemosensitivity to paclitaxel in epithelial ovarian carcinoma cells. Cancer Sci. 2010, 101, 347-354. [CrossRef] [PubMed]

44. Kajiyama, H.; Kikkawa, F.; Suzuki, T.; Shibata, K.; Ino, K.; Mizutani, S. Prolonged survival and decreased invasive activity attributable to dipeptidyl peptidase IV overexpression in ovarian carcinoma. Cancer Res. 2002, 62, 2753-2757. [PubMed]

45. Zhang, M.; Xu, L.; Wang, X.; Sun, B.; Ding, J. Expression levels of seprase/FAPalpha and DPPIV/CD26 in epithelial ovarian carcinoma. Oncol. Lett. 2015, 10, 34-42. [CrossRef]

46. Yan, L.; Tian, X.; Ye, C.; Guan, X.; Dong, B.; Zhao, M.; Wu, J.; Hao, C. CD26 as a Promising Biomarker for Predicting Prognosis in Patients with Pancreatic Tumors. Onco Targets Ther. 2020, 13, 12615-12623. [CrossRef] [PubMed]

47. Lu, Z.; Qi, L.; Bo, X.J.; Liu, G.D.; Wang, J.M.; Li, G. Expression of CD26 and CXCR4 in prostate carcinoma and its relationship with clinical parameters. J. Res. Med. Sci. 2013, 18, 647-652.

48. Song, Y.; Zhou, M.; Cao, Y.; Qi, J.; Geng, J.; Liu, X. Expression of GLP-1 receptor and CD26 in human thyroid C-cells: The association of thyroid C-cell tumorigenesis with incretin-based medicine. Oncol. Lett. 2017, 13, 2684-2690. [CrossRef] [PubMed]

49. Liang, P.I.; Yeh, B.W.; Li, W.M.; Chan, T.C.; Chang, I.W.; Huang, C.N.; Li, C.C.; Ke, H.L.; Yeh, H.C.; Wu, W.J.; et al. DPP4/CD26 overexpression in urothelial carcinoma confers an independent prognostic impact and correlates with intrinsic biological aggressiveness. Oncotarget 2017, 8, 2995-3008. [CrossRef]

50. Aldinucci, D.; Poletto, D.; Lorenzon, D.; Nanni, P.; Degan, M.; Olivo, K.; Rapana, B.; Pinto, A.; Gattei, V. CD26 expression correlates with a reduced sensitivity to 2 -deoxycoformycin-induced growth inhibition and apoptosis in T-cell leukemia/lymphomas. Clin. Cancer Res. 2004, 10, 508-520. [CrossRef] [PubMed]

51. Cro, L.; Morabito, F.; Zucal, N.; Fabris, S.; Lionetti, M.; Cutrona, G.; Rossi, F.; Gentile, M.; Ferrario, A.; Ferrarini, M.; et al. CD26 expression in mature B-cell neoplasia: Its possible role as a new prognostic marker in B-CLL. Hematol. Oncol. 2009, $27,140-147$. [CrossRef] [PubMed]

52. Matuszak, M.; Lewandowski, K.; Czyz, A.; Kiernicka-Parulska, J.; Przybylowicz-Chalecka, A.; Jarmuz-Szymczak, M.; Lewandowska, M.; Komarnicki, M. The prognostic significance of surface dipeptidylpeptidase IV (CD26) expression in B-cell chronic lymphocytic leukemia. Leuk. Res. 2016, 47, 166-171. [CrossRef]

53. Moffitt, L.R.; Bilandzic, M.; Wilson, A.L.; Chen, Y.; Gorrell, M.D.; Oehler, M.K.; Plebanski, M.; Stephens, A.N. Hypoxia Regulates DPP4 Expression, Proteolytic Inactivation, and Shedding from Ovarian Cancer Cells. Int J. Mol. Sci 2020, 21, 8110. [CrossRef]

54. Beckenkamp, A.; Willig, J.B.; Santana, D.B.; Nascimento, J.; Paccez, J.D.; Zerbini, L.F.; Bruno, A.N.; Pilger, D.A.; Wink, M.R.; Buffon, A. Differential Expression and Enzymatic Activity of DPPIV/CD26 Affects Migration Ability of Cervical Carcinoma Cells. PLoS ONE 2015, 10, e0134305. [CrossRef] [PubMed]

55. Wang, H.; Liu, X.; Long, M.; Huang, Y.; Zhang, L.; Zhang, R.; Zheng, Y.; Liao, X.; Wang, Y.; Liao, Q.; et al. NRF2 activation by antioxidant antidiabetic agents accelerates tumor metastasis. Sci. Transl. Med. 2016, 8, 334ra351. [CrossRef]

56. He, L.; Zhang, T.; Sun, W.; Qin, Y.; Wang, Z.; Dong, W.; Zhang, H. The DPP-IV inhibitor saxagliptin promotes the migration and invasion of papillary thyroid carcinoma cells via the NRF2/HO1 pathway. Med. Oncol. 2020, 37, 97. [CrossRef]

57. Piskounova, E.; Agathocleous, M.; Murphy, M.M.; Hu, Z.; Huddlestun, S.E.; Zhao, Z.; Leitch, A.M.; Johnson, T.M.; DeBerardinis, R.J.; Morrison, S.J. Oxidative stress inhibits distant metastasis by human melanoma cells. Nature 2015, 527, 186-191. [CrossRef] [PubMed]

58. Meyskens, F.L., Jr.; McNulty, S.E.; Buckmeier, J.A.; Tohidian, N.B.; Spillane, T.J.; Kahlon, R.S.; Gonzalez, R.I. Aberrant redox regulation in human metastatic melanoma cells compared to normal melanocytes. Free Radic. Biol. Med. 2001, 31, 799-808. [CrossRef]

59. Teicher, B.A.; Fricker, S.P. CXCL12 (SDF-1)/CXCR4 pathway in cancer. Clin. Cancer Res. 2010, 16, 2927-2931. [CrossRef]

60. Xu, C.; Zhao, H.; Chen, H.; Yao, Q. CXCR4 in breast cancer: Oncogenic role and therapeutic targeting. Drug Des. Dev. Ther. 2015, 9, 4953-4964. [CrossRef]

61. Sun, Y.X.; Pedersen, E.A.; Shiozawa, Y.; Havens, A.M.; Jung, Y.; Wang, J.; Pienta, K.J.; Taichman, R.S. CD26/dipeptidyl peptidase IV regulates prostate cancer metastasis by degrading SDF-1/CXCL12. Clin. Exp. Metastasis 2008, 25, 765-776. [CrossRef]

62. Yang, F.; Takagaki, Y.; Yoshitomi, Y.; Ikeda, T.; Li, J.; Kitada, M.; Kumagai, A.; Kawakita, E.; Shi, S.; Kanasaki, K.; et al. Inhibition of Dipeptidyl Peptidase-4 Accelerates Epithelial-Mesenchymal Transition and Breast Cancer Metastasis via the CXCL12/CXCR4/mTOR Axis. Cancer Res. 2019, 79, 735-746. [CrossRef] [PubMed]

63. Lamouille, S.; Connolly, E.; Smyth, J.W.; Akhurst, R.J.; Derynck, R. TGF-beta-induced activation of mTOR complex 2 drives epithelial-mesenchymal transition and cell invasion. J. Cell Sci. 2012, 125, 1259-1273. [CrossRef] [PubMed]

64. Katsuno, Y.; Meyer, D.S.; Zhang, Z.; Shokat, K.M.; Akhurst, R.J.; Miyazono, K.; Derynck, R. Chronic TGF-beta exposure drives stabilized EMT, tumor stemness, and cancer drug resistance with vulnerability to bitopic mTOR inhibition. Sci. Signal. $2019,12$. [CrossRef] [PubMed]

65. Du, L.; Li, X.; Zhen, L.; Chen, W.; Mu, L.; Zhang, Y.; Song, A. Everolimus inhibits breast cancer cell growth through PI3K/AKT/mTOR signaling pathway. Mol. Med. Rep. 2018, 17, 7163-7169. [CrossRef] [PubMed] 
66. Park, J.Y.; Kang, S.E.; Ahn, K.S.; Um, J.Y.; Yang, W.M.; Yun, M.; Lee, S.G. Inhibition of the PI3K-AKT-mTOR pathway suppresses the adipocyte-mediated proliferation and migration of breast cancer cells. J. Cancer 2020, 11, 2552-2559. [CrossRef] [PubMed]

67. Ippen, F.M.; Alvarez-Breckenridge, C.A.; Kuter, B.M.; Fink, A.L.; Bihun, I.V.; Lastrapes, M.; Penson, T.; Schmidt, S.P.; Wojtkiewicz, G.R.; Ning, J.; et al. The Dual PI3K/mTOR Pathway Inhibitor GDC-0084 Achieves Antitumor Activity in PIK3CA-Mutant Breast Cancer Brain Metastases. Clin. Cancer Res. 2019, 25, 3374-3383. [CrossRef]

68. Zhang, G.; Kim, S.; Gu, X.; Yu, S.P.; Wei, L. DPP-4 Inhibitor Linagliptin is Neuroprotective in Hyperglycemic Mice with Stroke via the AKT/mTOR Pathway and Anti-apoptotic Effects. Neurosci. Bull. 2020, 36, 407-418. [CrossRef]

69. El-Marasy, S.A.; Abdel-Rahman, R.F.; Abd-Elsalam, R.M. Neuroprotective effect of vildagliptin against cerebral ischemia in rats. Naunyn Schmiedebergs Arch. Pharmacol. 2018, 391, 1133-1145. [CrossRef]

70. Li, X.; Ma, G.; Ma, Q.; Li, W.; Liu, J.; Han, L.; Duan, W.; Xu, Q.; Liu, H.; Wang, Z.; et al. Neurotransmitter substance P mediates pancreatic cancer perineural invasion via NK-1R in cancer cells. Mol. Cancer Res. 2013, 11, 294-302. [CrossRef]

71. Cheng, Y.; Tang, X.Y.; Li, Y.X.; Zhao, D.D.; Cao, Q.H.; Wu, H.X.; Yang, H.B.; Hao, K.; Yang, Y. Depression-Induced Neuropeptide Y Secretion Promotes Prostate Cancer Growth by Recruiting Myeloid Cells. Clin. Cancer Res. 2019, 25, 2621-2632. [CrossRef] [PubMed]

72. Bronger, H.; Karge, A.; Dreyer, T.; Zech, D.; Kraeft, S.; Avril, S.; Kiechle, M.; Schmitt, M. Induction of cathepsin B by the CXCR3 chemokines CXCL9 and CXCL10 in human breast cancer cells. Oncol. Lett. 2017, 13, 4224-4230. [CrossRef] [PubMed]

73. Shin, S.Y.; Nam, J.S.; Lim, Y.; Lee, Y.H. TNFalpha-exposed bone marrow-derived mesenchymal stem cells promote locomotion of MDA-MB-231 breast cancer cells through transcriptional activation of CXCR3 ligand chemokines. J. Biol. Chem. 2010, 285, 30731-30740. [CrossRef]

74. Zipin-Roitman, A.; Meshel, T.; Sagi-Assif, O.; Shalmon, B.; Avivi, C.; Pfeffer, R.M.; Witz, I.P.; Ben-Baruch, A. CXCL10 promotes invasion-related properties in human colorectal carcinoma cells. Cancer Res. 2007, 67, 3396-3405. [CrossRef]

75. Zhou, H.; Wu, J.; Wang, T.; Zhang, X.; Liu, D. CXCL10/CXCR3 axis promotes the invasion of gastric cancer via PI3K/AKT pathway-dependent MMPs production. Biomed. Pharmacother. 2016, 82, 479-488. [CrossRef]

76. Li, S.; Fan, Y.; Kumagai, A.; Kawakita, E.; Kitada, M.; Kanasaki, K.; Koya, D. Deficiency in Dipeptidyl Peptidase-4 Promotes Chemoresistance through the CXCL12/CXCR4/mTOR/TGFbeta Signaling Pathway in Breast Cancer Cells. Int. J. Mol. Sci. 2020, 21, 805. [CrossRef]

77. Mizokami, Y.; Kajiyama, H.; Shibata, K.; Ino, K.; Kikkawa, F.; Mizutani, S. Stromal cell-derived factor-1alpha-induced cell proliferation and its possible regulation by CD26/dipeptidyl peptidase IV in endometrial adenocarcinoma. Int. J. Cancer 2004, 110, 652-659. [CrossRef] [PubMed]

78. Kodama, T.; Koma, Y.I.; Arai, N.; Kido, A.; Urakawa, N.; Nishio, M.; Shigeoka, M.; Yokozaki, H. CCL3-CCR5 axis contributes to progression of esophageal squamous cell carcinoma by promoting cell migration and invasion via Akt and ERK pathways. Lab. Investig. 2020, 100, 1140-1157. [CrossRef]

79. da Silva, J.M.; Moreira Dos Santos, T.P.; Sobral, L.M.; Queiroz-Junior, C.M.; Rachid, M.A.; Proudfoot, A.E.I.; Garlet, G.P.; Batista, A.C.; Teixeira, M.M.; Leopoldino, A.M.; et al. Relevance of CCL3/CCR5 axis in oral carcinogenesis. Oncotarget 2017, 8, 51024-51036. [CrossRef] [PubMed]

80. Walens, A.; DiMarco, A.V.; Lupo, R.; Kroger, B.R.; Damrauer, J.S.; Alvarez, J.V. CCL5 promotes breast cancer recurrence through macrophage recruitment in residual tumors. Elife 2019, 8. [CrossRef]

81. An, G.; Wu, F.; Huang, S.; Feng, L.; Bai, J.; Gu, S.; Zhao, X. Effects of CCL5 on the biological behavior of breast cancer and the mechanisms of its interaction with tumorassociated macrophages. Oncol. Rep. 2019, 42, 2499-2511. [CrossRef] [PubMed]

82. D’Esposito, V.; Liguoro, D.; Ambrosio, M.R.; Collina, F.; Cantile, M.; Spinelli, R.; Raciti, G.A.; Miele, C.; Valentino, R.; Campiglia, P.; et al. Adipose microenvironment promotes triple negative breast cancer cell invasiveness and dissemination by producing CCL5. Oncotarget 2016, 7, 24495-24509. [CrossRef]

83. Zhao, R.; Bei, X.; Yang, B.; Wang, X.; Jiang, C.; Shi, F.; Wang, X.; Zhu, Y.; Jing, Y.; Han, B.; et al. Endothelial cells promote metastasis of prostate cancer by enhancing autophagy. J. Exp. Clin. Cancer Res. 2018, 37, 221. [CrossRef] [PubMed]

84. Singh, S.K.; Mishra, M.K.; Eltoum, I.A.; Bae, S.; Lillard, J.W., Jr.; Singh, R. CCR5/CCL5 axis interaction promotes migratory and invasiveness of pancreatic cancer cells. Sci. Rep. 2018, 8, 1323. [CrossRef] [PubMed]

85. Tian, M.; Chen, L.; Ma, L.; Wang, D.; Shao, B.; Wu, J.; Wu, H.; Jin, Y. Expression and prognostic significance of CCL11/CCR3 in glioblastoma. Oncotarget 2016, 7, 32617-32627. [CrossRef] [PubMed]

86. Gu, Y.; Li, X.; Bi, Y.; Zheng, Y.; Wang, J.; Li, X.; Huang, Z.; Chen, L.; Huang, Y.; Huang, Y. CCL14 is a prognostic biomarker and correlates with immune infiltrates in hepatocellular carcinoma. Aging (Albany NY) 2020, 12, 784-807. [CrossRef] [PubMed]

87. Cai, Y.; Ling, Y.; Huang, L.; Huang, H.; Chen, X.; Xiao, Y.; Zhu, Z.; Chen, J. C-C motif chemokine 14 as a novel potential biomarker for predicting the prognosis of epithelial ovarian cancer. Oncol. Lett. 2020, 19, 2875-2883. [CrossRef]

88. Li, Q.; Shi, L.; Gui, B.; Yu, W.; Wang, J.; Zhang, D.; Han, X.; Yao, Z.; Shang, Y. Binding of the JmjC demethylase JARID1B to LSD1/NuRD suppresses angiogenesis and metastasis in breast cancer cells by repressing chemokine CCL14. Cancer Res. 2011, 71, 6899-6908. [CrossRef] [PubMed]

89. Yan, G.; Li, S.; Yue, M.; Li, C.; Kang, Z. Lysine demethylase 5B suppresses CC chemokine ligand 14 to promote progression of colorectal cancer through the Wnt/beta-catenin pathway. Life Sci. 2021, 264, 118726. [CrossRef]

90. Zhu, M.; Xu, W.; Wei, C.; Huang, J.; Xu, J.; Zhang, Y.; Zhao, Y.; Chen, J.; Dong, S.; Liu, B.; et al. CCL14 serves as a novel prognostic factor and tumor suppressor of HCC by modulating cell cycle and promoting apoptosis. Cell Death Dis. 2019, 10, 796. [CrossRef] 
91. Huang, Y.H.; Chang, C.Y.; Kuo, Y.Z.; Fang, W.Y.; Kao, H.Y.; Tsai, S.T.; Wu, L.W. Cancer-associated fibroblast-derived interleukin1beta activates protumor C-C motif chemokine ligand 22 signaling in head and neck cancer. Cancer Sci. 2019, 110, $2783-2793$. [CrossRef] [PubMed]

92. Curiel, T.J.; Coukos, G.; Zou, L.; Alvarez, X.; Cheng, P.; Mottram, P.; Evdemon-Hogan, M.; Conejo-Garcia, J.R.; Zhang, L.; Burow, M.; et al. Specific recruitment of regulatory $\mathrm{T}$ cells in ovarian carcinoma fosters immune privilege and predicts reduced survival. Nat. Med. 2004, 10, 942-949. [CrossRef] [PubMed]

93. Tsujikawa, T.; Yaguchi, T.; Ohmura, G.; Ohta, S.; Kobayashi, A.; Kawamura, N.; Fujita, T.; Nakano, H.; Shimada, T.; Takahashi, T.; et al. Autocrine and paracrine loops between cancer cells and macrophages promote lymph node metastasis via CCR4/CCL22 in head and neck squamous cell carcinoma. Int. J. Cancer 2013, 132, 2755-2766. [CrossRef]

94. Begicevic, R.R.; Falasca, M. ABC Transporters in Cancer Stem Cells: Beyond Chemoresistance. Int. J. Mol. Sci. 2017, 18, 2362. [CrossRef]

95. Choi, C.H. ABC transporters as multidrug resistance mechanisms and the development of chemosensitizers for their reversal. Cancer Cell Int. 2005, 5, 30. [CrossRef] [PubMed]

96. Scirica, B.M.; Bhatt, D.L.; Braunwald, E.; Steg, P.G.; Davidson, J.; Hirshberg, B.; Ohman, P.; Frederich, R.; Wiviott, S.D.; Hoffman, E.B.; et al. Saxagliptin and cardiovascular outcomes in patients with type 2 diabetes mellitus. N. Engl. J. Med. 2013, 369, 1317-1326. [CrossRef] [PubMed]

97. White, W.B.; Cannon, C.P.; Heller, S.R.; Nissen, S.E.; Bergenstal, R.M.; Bakris, G.L.; Perez, A.T.; Fleck, P.R.; Mehta, C.R.; Kupfer, S.; et al. Alogliptin after acute coronary syndrome in patients with type 2 diabetes. N. Engl. J. Med. 2013, 369, 1327-1335. [CrossRef] [PubMed]

98. Green, J.B.; Bethel, M.A.; Armstrong, P.W.; Buse, J.B.; Engel, S.S.; Garg, J.; Josse, R.; Kaufman, K.D.; Koglin, J.; Korn, S.; et al. Effect of Sitagliptin on Cardiovascular Outcomes in Type 2 Diabetes. N. Engl. J. Med. 2015, 373, 232-242. [CrossRef]

99. Rosenstock, J.; Perkovic, V.; Johansen, O.E.; Cooper, M.E.; Kahn, S.E.; Marx, N.; Alexander, J.H.; Pencina, M.; Toto, R.D.; Wanner, C.; et al. Effect of Linagliptin vs Placebo on Major Cardiovascular Events in Adults with Type 2 Diabetes and High Cardiovascular and Renal Risk: The CARMELINA Randomized Clinical Trial. JAMA 2019, 321, 69-79. [CrossRef]

100. Leiter, L.A.; Teoh, H.; Mosenzon, O.; Cahn, A.; Hirshberg, B.; Stahre, C.A.; Hoekstra, J.B.; Alvarsson, M.; Im, K.; Scirica, B.M.; et al. Frequency of cancer events with saxagliptin in the SAVOR-TIMI 53 trial. Diabetes Obes. Metab. 2016, 18, 186-190. [CrossRef]

101. Matthews, D.R.; Paldanius, P.M.; Proot, P.; Chiang, Y.; Stumvoll, M.; Del Prato, S.; VERIFY Study Group. Glycaemic durability of an early combination therapy with vildagliptin and metformin versus sequential metformin monotherapy in newly diagnosed type 2 diabetes (VERIFY): A 5-year, multicentre, randomised, double-blind trial. Lancet 2019, 394, 1519-1529. [CrossRef]

102. Elashoff, M.; Matveyenko, A.V.; Gier, B.; Elashoff, R.; Butler, P.C. Pancreatitis, pancreatic, and thyroid cancer with glucagon-like peptide-1-based therapies. Gastroenterology 2011, 141, 150-156. [CrossRef] [PubMed]

103. Chiu, W.Y.; Shih, S.R.; Tseng, C.H. A review on the association between glucagon-like peptide-1 receptor agonists and thyroid cancer. Exp. Diabetes Res. 2012, 2012, 924168. [CrossRef] [PubMed]

104. Tseng, C.H.; Lee, K.Y.; Tseng, F.H. An updated review on cancer risk associated with incretin mimetics and enhancers. J. Environ. Sci. Health C Environ. Carcinog Ecotoxicol. Rev. 2015, 33, 67-124. [CrossRef] [PubMed]

105. Tseng, C.H. Sitagliptin use and thyroid cancer risk in patients with type 2 diabetes. Oncotarget 2016, 7, 24871-24879. [CrossRef] [PubMed]

106. Dore, D.D.; Seeger, J.D.; Chan, K.A. Incidence of health insurance claims for thyroid neoplasm and pancreatic malignancy in association with exenatide: Signal refinement using active safety surveillance. Ther. Adv. Drug Saf. 2012, 3, 157-164. [CrossRef] [PubMed]

107. Romley, J.A.; Goldman, D.P.; Solomon, M.; McFadden, D.; Peters, A.L. Exenatide therapy and the risk of pancreatitis and pancreatic cancer in a privately insured population. Diabetes Technol. Ther. 2012, 14, 904-911. [CrossRef]

108. Funch, D.; Gydesen, H.; Tornoe, K.; Major-Pedersen, A.; Chan, K.A. A prospective, claims-based assessment of the risk of pancreatitis and pancreatic cancer with liraglutide compared to other antidiabetic drugs. Diabetes Obes. Metab. 2014, 16, $273-275$. [CrossRef]

109. Gokhale, M.; Buse, J.B.; Gray, C.L.; Pate, V.; Marquis, M.A.; Sturmer, T. Dipeptidyl-peptidase-4 inhibitors and pancreatic cancer: A cohort study. Diabetes Obes. Metab. 2014, 16, 1247-1256. [CrossRef] [PubMed]

110. Tseng, C.H. Sitagliptin and pancreatic cancer risk in patients with type 2 diabetes. Eur. J. Clin. Investig. 2016, 46, 70-79. [CrossRef]

111. Knapen, L.M.; van Dalem, J.; Keulemans, Y.C.; van Erp, N.P.; Bazelier, M.T.; De Bruin, M.L.; Leufkens, H.G.; Croes, S.; Neef, C.; de Vries, F.; et al. Use of incretin agents and risk of pancreatic cancer: A population-based cohort study. Diabetes Obes. Metab. 2016, 18, 258-265. [CrossRef] [PubMed]

112. Azoulay, L. Incretin-based drugs and adverse pancreatic events: Almost a decade later and uncertainty remains. Diabetes Care 2015, 38, 951-953. [CrossRef] [PubMed]

113. Egan, A.G.; Blind, E.; Dunder, K.; de Graeff, P.A.; Hummer, B.T.; Bourcier, T.; Rosebraugh, C. Pancreatic safety of incretin-based drugs-FDA and EMA assessment. N. Engl. J. Med. 2014, 370, 794-797. [CrossRef] [PubMed]

114. Abd El Aziz, M.; Cahyadi, O.; Meier, J.J.; Schmidt, W.E.; Nauck, M.A. Incretin-based glucose-lowering medications and the risk of acute pancreatitis and malignancies: A meta-analysis based on cardiovascular outcomes trials. Diabetes Obes. Metab. 2020, 22, 699-704. [CrossRef] [PubMed] 
115. Boniol, M.; Franchi, M.; Bota, M.; Leclercq, A.; Guillaume, J.; van Damme, N.; Corrao, G.; Autier, P.; Boyle, P. Incretin-Based Therapies and the Short-term Risk of Pancreatic Cancer: Results From Two Retrospective Cohort Studies. Diabetes Care 2018, 41, 286-292. [CrossRef] [PubMed]

116. Lee, M.; Sun, J.; Han, M.; Cho, Y.; Lee, J.Y.; Nam, C.M.; Kang, E.S. Nationwide Trends in Pancreatitis and Pancreatic Cancer Risk Among Patients with Newly Diagnosed Type 2 Diabetes Receiving Dipeptidyl Peptidase 4 Inhibitors. Diabetes Care 2019, 42, 2057-2064. [CrossRef]

117. Choi, Y.J.; Kim, D.J.; Shin, S. Incident cancer risk in dipeptidyl peptidase-4 inhibitor-treated patients with type 2 diabetes mellitus. Cancer Manag. Res. 2019, 11, 7427-7438. [CrossRef] [PubMed]

118. Abrahami, D.; Douros, A.; Yin, H.; Yu, O.H.; Faillie, J.L.; Montastruc, F.; Platt, R.W.; Bouganim, N.; Azoulay, L. Incretin based drugs and risk of cholangiocarcinoma among patients with type 2 diabetes: Population based cohort study. BMJ 2018, $363, \mathrm{k} 4880$. [CrossRef]

119. Marzioni, M.; Alpini, G.; Saccomanno, S.; Candelaresi, C.; Venter, J.; Rychlicki, C.; Fava, G.; Francis, H.; Trozzi, L.; Glaser, S.; et al. Glucagon-like peptide- 1 and its receptor agonist exendin-4 modulate cholangiocyte adaptive response to cholestasis. Gastroenterology 2007, 133, 244-255. [CrossRef]

120. Chen, B.D.; Zhao, W.C.; Dong, J.D.; Sima, H. Expression of GLP-1R protein and its clinical role in intrahepatic cholangiocarcinoma tissues. Mol. Biol. Rep. 2014, 41, 4313-4320. [CrossRef] [PubMed]

121. Marzioni, M.; Alpini, G.; Saccomanno, S.; Candelaresi, C.; Venter, J.; Rychlicki, C.; Fava, G.; Francis, H.; Trozzi, L.; Benedetti, A. Exendin-4, a glucagon-like peptide 1 receptor agonist, protects cholangiocytes from apoptosis. Gut 2009, 58, 990-997. [CrossRef] [PubMed]

122. Abrahami, D.; Yin, H.; Yu, O.H.Y.; Pollak, M.N.; Azoulay, L. Incretin-based Drugs and the Incidence of Colorectal Cancer in Patients with Type 2 Diabetes. Epidemiology 2018, 29, 246-253. [CrossRef] [PubMed]

123. Dicembrini, I.; Nreu, B.; Montereggi, C.; Mannucci, E.; Monami, M. Risk of cancer in patients treated with dipeptidyl peptidase-4 inhibitors: An extensive meta-analysis of randomized controlled trials. Acta Diabetol. 2020, 57, 689-696. [CrossRef] [PubMed]

124. Ueki, K.; Tanizawa, Y.; Nakamura, J.; Yamada, Y.; Inagaki, N.; Watada, H.; Shimomura, I.; Nishimura, R.; Miyoshi, H.; Abiko, A.; et al. Long-term safety and efficacy of alogliptin, a DPP-4 inhibitor, in patients with type 2 diabetes: A 3-year prospective, controlled, observational study (J-BRAND Registry). BMJ Open Diabetes Res. Care 2021, 9. [CrossRef] [PubMed]

125. Zhao, M.; Chen, J.; Yuan, Y.; Zou, Z.; Lai, X.; Rahmani, D.M.; Wang, F.; Xi, Y.; Huang, Q.; Bu, S. Dipeptidyl peptidase-4 inhibitors and cancer risk in patients with type 2 diabetes: A meta-analysis of randomized clinical trials. Sci. Rep. 2017, 7, 8273. [CrossRef] [PubMed]

126. Chai, S.; Yu, S.; Yang, Z.; Wu, S.; Gao, L.; Wang, H.; Zhang, Y.; Zhan, S.; Ji, L.; Sun, F. Effect of incretin-based therapies on cancers of digestive system among 101595 patients with type 2 diabetes mellitus: A systematic review and network meta-analysis combining 84 trials with a median duration of 30 weeks. BMJ Open Diabetes Res. Care 2019, 7, e000728. [CrossRef] [PubMed]

127. Stattin, P.; Bjor, O.; Ferrari, P.; Lukanova, A.; Lenner, P.; Lindahl, B.; Hallmans, G.; Kaaks, R. Prospective study of hyperglycemia and cancer risk. Diabetes Care 2007, 30, 561-567. [CrossRef]

128. Shah, C.; Hong, Y.R.; Bishnoi, R.; Ali, A.; Skelton, W.P.t.; Dang, L.H.; Huo, J.; Dang, N.H. Impact of DPP4 Inhibitors in Survival of Patients With Prostate, Pancreas, and Breast Cancer. Front. Oncol. 2020, 10, 405. [CrossRef]

129. Ali, A.; Fuentes, A.; Skelton, W.I.; Wang, Y.; McGorray, S.; Shah, C.; Bishnoi, R.; Dang, L.H.; Dang, N.H. A multi-center retrospective analysis of the effect of DPP4 inhibitors on progression-free survival in advanced airway and colorectal cancers. Mol. Clin. Oncol. 2019, 10, 118-124. [CrossRef]

130. Noh, Y.; Jeon, S.M.; Shin, S. Association between glucose-lowering treatment and cancer metastasis among patients with preexisting type 2 diabetes and incident malignancy. Int. J. Cancer 2019, 144, 1530-1539. [CrossRef]

131. Rathmann, W.; Kostev, K. Association of dipeptidyl peptidase 4 inhibitors with risk of metastases in patients with type 2 diabetes and breast, prostate or digestive system cancer. J. Diabetes Complicat. 2017, 31, 687-692. [CrossRef] [PubMed]

132. Vihervuori, V.J.; Talala, K.; Taari, K.; Lahtela, J.; Tammela, T.; Auvinen, A.; Raittinen, P.V.H.; Murtola, T.J. Antidiabetic drugs and prostate cancer prognosis in a Finnish population-based cohort. Cancer Epidemiol. Biomark. Prev. 2021. [CrossRef]

133. Villarreal-Garza, C.; Shaw-Dulin, R.; Lara-Medina, F.; Bacon, L.; Rivera, D.; Urzua, L.; Aguila, C.; Ramirez-Morales, R.; Santamaria, J.; Bargallo, E.; et al. Impact of diabetes and hyperglycemia on survival in advanced breast cancer patients. Exp. Diabetes Res. 2012, 2012, 732027. [CrossRef] [PubMed]

134. Li, J.; Ning, N.Y.; Rao, Q.X.; Chen, R.; Wang, L.J.; Lin, Z.Q. Pretreatment glycemic control status is an independent prognostic factor for cervical cancer patients receiving neoadjuvant chemotherapy for locally advanced disease. BMC Cancer 2017, 17, 517. [CrossRef] [PubMed]

135. Alpertunga, I.; Sadiq, R.; Pandya, D.; Lo, T.; Dulgher, M.; Evans, S.; Bennett, B.; Rennert, N.; Frank, R.C. Glycemic Control as an Early Prognostic Marker in Advanced Pancreatic Cancer. Front. Oncol. 2021, 11, 571855. [CrossRef]

136. Pillozzi, S.; Bernini, A.; Spiga, O.; Lelli, B.; Petroni, G.; Bracci, L.; Niccolai, N.; Arcangeli, A. Peptides and small molecules blocking the CXCR4/CXCL12 axis overcome bone marrowinduced chemoresistance in acute leukemias. Oncol. Rep. 2019, 41, 312-324. [CrossRef]

137. Zhang, F.; Cui, J.Y.; Gao, H.F.; Yu, H.; Gao, F.F.; Chen, J.L.; Chen, L. Cancer-associated fibroblasts induce epithelial-mesenchymal transition and cisplatin resistance in ovarian cancer via CXCL12/CXCR4 axis. Future Oncol. 2020, 16, 2619-2633. [CrossRef] 
138. Currie, C.J.; Poole, C.D.; Gale, E.A. The influence of glucose-lowering therapies on cancer risk in type 2 diabetes. Diabetologia 2009, 52, 1766-1777. [CrossRef] [PubMed]

139. Col, N.F.; Ochs, L.; Springmann, V.; Aragaki, A.K.; Chlebowski, R.T. Metformin and breast cancer risk: A meta-analysis and critical literature review. Breast Cancer Res. Treat. 2012, 135, 639-646. [CrossRef]

140. Currie, C.J.; Poole, C.D.; Jenkins-Jones, S.; Gale, E.A.; Johnson, J.A.; Morgan, C.L. Mortality after incident cancer in people with and without type 2 diabetes: Impact of metformin on survival. Diabetes Care 2012, 35, 299-304. [CrossRef]

141. Pimentel, I.; Lohmann, A.E.; Ennis, M.; Dowling, R.J.O.; Cescon, D.; Elser, C.; Potvin, K.R.; Haq, R.; Hamm, C.; Chang, M.C.; et al. A phase II randomized clinical trial of the effect of metformin versus placebo on progression-free survival in women with metastatic breast cancer receiving standard chemotherapy. Breast 2019, 48, 17-23. [CrossRef]

142. Nanni, O.; Amadori, D.; De Censi, A.; Rocca, A.; Freschi, A.; Bologna, A.; Gianni, L.; Rosetti, F.; Amaducci, L.; Cavanna, L.; et al. Metformin plus chemotherapy versus chemotherapy alone in the first-line treatment of HER2-negative metastatic breast cancer. The MYME randomized, phase 2 clinical trial. Breast Cancer Res. Treat. 2019, 174, 433-442. [CrossRef] [PubMed]

143. Wu, Z.; Qu, B.; Huang, X.; Song, Y.; Gao, P.; Shi, J.; Zhou, C.; Wang, Z. The potential adjunctive benefit of adding metformin to standard treatment in inoperable cancer patients: A meta-analysis of randomized controlled trials. Ann. Transl. Med. 2020, 8, 1404. [CrossRef]

144. Hirsch, H.A.; Iliopoulos, D.; Tsichlis, P.N.; Struhl, K. Metformin selectively targets cancer stem cells, and acts together with chemotherapy to block tumor growth and prolong remission. Cancer Res. 2009, 69, 7507-7511. [CrossRef] [PubMed]

145. Zhang, C.; Wang, Y. Metformin attenuates cells stemness and epithelialmesenchymal transition in colorectal cancer cells by inhibiting the Wnt3a/betacatenin pathway. Mol. Med. Rep. 2019, 19, 1203-1209. [CrossRef] [PubMed]

146. Park, M.J.; Moon, S.J.; Baek, J.A.; Lee, E.J.; Jung, K.A.; Kim, E.K.; Kim, D.S.; Lee, J.H.; Kwok, S.K.; Min, J.K.; et al. Metformin Augments Anti-Inflammatory and Chondroprotective Properties of Mesenchymal Stem Cells in Experimental Osteoarthritis. J. Immunol. 2019, 203, 127-136. [CrossRef] [PubMed] 